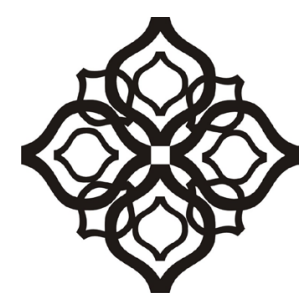

Shirkah

Journal of Economics and Business 


\section{Shirkah}

Journal of Economics and Business

Vol. 3, No. 2, May-August 2018

ISSN: 2503-4235 (p); 2503-4243 (e)

\section{Editor in Chief}

Dwi Condro Triono

\section{Managing Editor}

Jasanta Peranginangin

\section{Editorial Boards}

Abdul Azim Islahi,

Islamic Economics Institute, King Abdulaziz University, Saudi Arabia

Abu Umar Faruq Ahmad,

UBD School of Business and Economics Universiti, Brunei Darussalam

Cedomir Nestorovic,

ESSEC Business School Asia Pacific, Singapore

Fitri Wulandari,

Faculty of Islamic Economics and Business, IAIN Surakarta, Indonesia

Johan Fischer,

Department of Social Sciences and Business Roskilde Universitetscenter, Denmark Muhamed Zulkhibri,

Islamic Research and Training Institute, Islamic Development Bank, Saudi Arabia M. Kabir Hassan,

Department of Economics and Finance, University of New Orleans, United States Musa Asy'arie,

Faculty of Islamic Economics and Business, IAIN Surakarta, Indonesia Nunung Nurul Hidayah,

Aston Business School, Aston University, Birmingham, United Kingdom

Saim Kayadibi,

Department of Economics, Kulliyyah of Economics and Management Science, International Islamic University Malaysia, Malaysia 
Shaikh M Ghazanfar,

Departement of Economics, University of Idaho, Russian Federation

Sigit S. Wibowo,

Department of Management, Faculty of Economics and Business, Universitas Indonesia, Indonesia

Vihang R. Errunza,

Desmarais Global Finance Research Centre, Desautels Faculty and Management, McGill University, Canada

\section{Assistant to Editor}

M. Endy Saputro

M. Zainal Anwar

Shirkah Journal of Economics and Business is a peer-reviewed journal published three times a year (January-April, May-August and September-December) by Faculty of Islamic Economics and Business, Institut Agama Islam Negeri (IAIN) Surakarta Central Java, Indonesia. The main objective of Shirkah is to offer an academic space of exchange ideas and initiate the increase number of qualified article produced by postgraduate students, practitioners and academicians.

\section{Editorial Office}

Ruang Jurnal Shirkah

Lantai Dasar, Sayap Barat, Fakultas Ekonomi dan Bisnis Islam, IAIN Surakarta

Jln. Pandawa No. 1, Kartasura, Sukoharjo, Jawa Tengah Kode Pos. 57168

Phone (+62271) 781516 Fax: (+62271)782336

E-mail: shirkahjournal@iainsurakarta.ac.id; shirkahiainsurakarta@gmail.com Website: http://shirkah.or.id/ 


\section{Shirkah}

\section{Journal of Economics and Business}

Vol. 3, No. 2, May-August 2018

ISSN: 2503-4235 (p); 2503-4243 (e)

\section{Table of Contents}

\section{Articles}

Eko Fajar Cabyono

Lina Nugraha Rani

Macroprudential Policy on Sharia Banking Financing

The Indonesian Experience

Yulianti

Seeing a Buddhist Doing Business in Contemporary Indonesia An Interview with Mr. Sudhamek A.W.S

Fransisca Dwijayanti

Making Economics of Piety

Fashion, Lifestyle and Identity in Pop-Islamism Turn

Indah Piliyanti

Fintech Achieving Sustainable Development

The Side Perspective of Crowdfunding Platform

Taufik Nugroho

Aam S. Rusydiana

Macroeconomic Variables on Indonesian Sharia Capital Market

Hurdle Rate and Adverse Selection on Escalation of Commitment 


\title{
Macroeconomic Variables on Indonesian Sharia Capital Market
}

\author{
Taufik Nugroho \\ SMART Consulting Indonesia \\ taufik.nugroho@gmail.com \\ Aam S. Rusydiana \\ SMART Consulting Indonesia \\ aansmart@gmail.com
}

\begin{abstract}
This article emphasizes to analyze the effect of macroeconomic variables on sharia capital market in Indonesia by using Vector Error Correlation Model (VECM) approach method. The variables used are world oil price, Industry Production Index (IPI) Currency Exchange Rate to Dollar and Consumer Price Index (CPI) in Indonesia. The research show that in the Indonesian Sharia Stock Index (ISSI) model, the VECM in the ISSI model can explain in the short term the IPI variable, world oil price, rupiah to dollar, DJIA and CPI does not affect to ISSI variable. While in the long term, world oil prices are positive climate and Dow Jones Industrial Average (DJIA) variables negatively affect ISSI. In addition, FEVD test the world oil price has more dominant contribution than other variable $6.02 \%$.
\end{abstract}

Keywords: sharia capital market, macroeconomics, VECM, ISSI

\section{Introduction}

Such have been empirical studies over the last few years seek to investigate the dynamic relationship between stock prices and macroeconomic variables in both developed and developing countries. Beik (2014) examine the Influence of Sharia International Stock Price Index and macroeconomic variable to Jakarta Islam Index. The results of his study showed that JII was positively and significantly influenced 
by DJIEU, DJIMY and IPI and was advised negatively and significantly by DJIJP.IMUS, M2 and SBIS. Asmy et al (2010) have tested the shortterm and long-term causal relationships between the qualities of the index mud and macroeconomic variables such as inflation (Aisiyah, 2015). The amount of money subsided and the exchange rate in the period before and after the crisis in the period 1987-1995 and from 1999-2007. In the results showed that inflation, money supply and exchange rate significant effect on the Kuala Lumpur index.

Naseri \& Masih (2014) have analyzed the causal cause between FTSE Sharia Malayisa Gold Shria Index and three macroeconomic variables, those are money supply, CPI and Exchange rate in Malaysia. These are cointegration tendency among syariah stock index with selected macroeconomic variable as expected (Dimic, Kiviaho, Piljak, \& Äijö, 2016). Khan (2014) shows that in the first equation of the sharia index (FTSHA), which cointegrated with interest rate (IR) and industrial production index (IPI), these two equations identify that the interst rate and IPI have no significant effect. Al-Majali (2014) analyzes the short-and long-term relationship between capital market index and macroeconomic variable performance in Jordan. It shows that the coefficient of ECT displays significant and negative influence especially for CPI and DR, while ECT in global finance wquation of crisis is not significant. This confirms Johansen's cointegration test presented earlier showing a longterm bi-directional relationship between stock and lending price indices for the private sector. The weighted average rates of time deposit interest and the consumer price index. However, the speed of balance adjustment is relatively slow in all equations.

Hsing (2011) on macroeconomic determinants of capital market indices and policy implications in Europe discusses the relationship between Hungarian stock market indices and relevant macroeconomic 
variables. He found that the Hungarian stock market index has a positive relationship with real GDP, the ratio of government debt to GDP, the nominal effective exchange rate and the German stock market index. Negative relationship with real interest rate. Expected inflation rate and government bond yields in the Euro area and quadratic relationship with real money supply M2. This suggests that there is a positive relationship if real M2 money supply is less (greater) than the critical value of 9.563 billion forint. If the quadratic relationship is not specified and tested. The real positive M2 coefficient will be insignificant at 10\% level. We can reach a misleading conclusion that the stock market indices are not significantly affected by M2. On the effect of macroeconomic variable stowards ISSI has also been conducted by such research as Syafii (2013), Fareed, Arsalan, \& Ayubi (2017) and Aisyah (2015). This article examines the effect of macroeconomic variables on sharia capital market in Indonesia by using Vector Error Correlation Model (VECM) approach method.

\section{Research Method}

Equation model applied in this research refers to a model of Sharia Capital Market Indonesia which represent with ISSI (Indonesian Sharia Stock Index). This articleemploys five variables of Vector Autoregression model (VAR) or Vector Error Correction Model (VECM). The following equation was being obtained from the equation of Sharia Capital Market in Indonesia. 
VAR Equation:

$\left[\begin{array}{c}\operatorname{lnissi}_{t} \\ \operatorname{lnIPI}_{t} \\ \ln C P I \\ \ln O I L_{t} \\ \ln D J I A \\ \ln E R_{t}\end{array}\right]=\left[\begin{array}{l}a 10 \\ a 20 \\ a 30 \\ a 40 \\ a 50 \\ a 60\end{array}\right]+\left[\begin{array}{ccccc}\beta 11 & \beta 12 & \beta 13 & \beta 14 & \beta 15 \\ \beta 21 & \beta 22 & \beta 23 & \beta 24 & \beta 25 \\ \beta 31 & \beta 32 & \beta 33 & \beta 34 & \beta 35 \\ \beta 41 & \beta 42 & \beta 43 & \beta 44 & \beta 45 \\ \beta 51 & \beta 452 & \beta 53 & \beta 54 & \beta 55 \\ \beta 61 & \beta 462 & \beta 63 & \beta 64 & \beta 65\end{array}\right]\left[\begin{array}{c}\ln I S S I_{t-1} \\ \ln I P I_{t-1} \\ \ln C P I_{t-1} \\ \ln O I L_{t-1} \\ \ln D I A \\ \ln E R R_{t-1}\end{array}\right]+\left[\begin{array}{c}\varepsilon_{1 t} \\ \varepsilon_{2 t} \\ \varepsilon_{3 t} \\ \varepsilon_{4 t} \\ \varepsilon_{5 t} \\ \varepsilon_{6 t}\end{array}\right]$

VECM Equation:

$\left[\begin{array}{c}\Delta i_{S S i_{t}} \\ \Delta I P I_{t} \\ \Delta C P I \\ \Delta O I L_{t} \\ \Delta D J I A^{\prime} \\ \Delta E R_{t}\end{array}\right]=\left[\begin{array}{l}a 10 \\ a 20 \\ a 30 \\ a 40 \\ a 50 \\ a 60\end{array}\right]+\left[\begin{array}{ccccc}\beta 11 & \beta 12 & \beta 13 & \beta 14 & \beta 15 \\ \beta 21 & \beta 22 & \beta 23 & \beta 24 & \beta 25 \\ \beta 31 & \beta 32 & \beta 33 & \beta 34 & \beta 35 \\ \beta 41 & \beta 42 & \beta 43 & \beta 44 & \beta 45 \\ \beta 51 & \beta 452 & \beta 53 & \beta 54 & \beta 55 \\ \beta 61 & \beta 462 & \beta 63 & \beta 64 & \beta 65\end{array}\right]\left[\begin{array}{c}\Delta I S S I_{t-1} \\ \Delta I P I_{t-1} \\ \Delta C P I_{t-1} \\ \Delta O I L_{t-1} \\ \Delta D J I \\ \Delta E R_{t-1}\end{array}\right]-\lambda\left[\begin{array}{l}\varepsilon_{1 t} \\ \varepsilon_{2 t} \\ \varepsilon_{3 t} \\ \varepsilon_{4 t} \\ \varepsilon_{5 t} \\ \varepsilon_{6 t}\end{array}\right]$

The test method proposes to test the stationarity of data for which is the ADF (Augmented Dickey Fuller) test using the five percent real level $(\forall=5 \%)$. If the value of $t-A D F$ is less than the critical value of MacKinnon, it may assume that the data is stationary (does not contain the root of the unit). Testing at the roots of this unit would be at the level up to the first difference. The gathered data was derived from those which does not contain the root of the unit. According to Gujarati (2003, p. 853), if the data used contains elements of the root of the unit,it will be difficult to estimate a model because the data tends to fluctuate not around its mean value. The next step is to test the stability of the VAR model, using the stationary data (the first difference data), not level data. The stability of the VAR model have been analyzed from the inverse roots value of its polynomial AR characteristics. A VAR system is considered stable if all of its roots have a modulus smaller than one (Gujarati, 2003).

Optimum lag test is performed to make a good VAR model with determination of optimum lag length. The determination of the number 
of lags (orders) to be used in the VAR model can be determined based on the Akaike Information Criterion (AIC), Schwarz Information Criterion (SC) or Hannan Quinnon Criterion (HQ) (Arsana, 2004, p. 6). The lag to be chosen in this research model is the model with the least value, because according to (Gujarati, 2003) too much lag length will increase degrees of freedom. In doing so, a smaller lag is recommended to minimize the specification of autocorrelation problems in the VAR system. Using optimal lag is expected no longer appear problem autocorrelation.

Cointegration test is conducted to see if there is cointegration between variables. Two variables will be cointegrated if the two variables have a long-term relationship or a balance relationship between them (Gujarati, 2003). The existence of cointegration between variables is a condition of whether or not the data is processed by the VECM method. Long-term information can be obtained by the first determining of the cointegration rank to find out how many systems of equations can explain from the whole system. According Arsana (2004, p. 7) determination of the number of cointegration relationships between variables can be seen from the value of his trace statistics. Trace statistic value exceeding its critical value indicates that there is cointegration in the model used.

IRF analysis aims to determine the response of the dependent variable in the VAR system due to shocks in error terms for some future periods (Gujarati, 2003). Estimates made for IRF are focused on the response of a variable on the change of one standard deviation from the variable itself or from other variables contained in the model. In other words, the function of impulse response determines the effect of a variable on a particular variable in case of shock. Another IRF function is to know the value of shocks to the existing variables.

FEVD analysis predicts how big the contribution of each variable to the change of certain variables (Ascarya, 2009, p. 19). This method 
characterizes a dynamic structure in the VAR model. This method can see the strengths and weaknesses of each variable in influencing other variables over a long period of time.

\section{Estimation of VESM Model}

Table 1. Short-Term

\begin{tabular}{|l|l|l|}
\hline \multicolumn{3}{|c|}{ Short Term (ISSI) } \\
\hline Variabel & koefesien & T-statistics \\
\hline CointEq1 & -0.00486 & {$[-0.55643]$} \\
\hline D(ISSI(-1)) & -0.00712 & {$[-0.05403]$} \\
\hline D(IPI_IND(-1)) & 0.553891 & {$[0.03507]$} \\
\hline D(OIL(-1)) & 2.761146 & {$[1.47021]$} \\
\hline D(ER_IND(-1)) & -6.37235 & {$[-0.84098]$} \\
\hline D(DJIA(-1)) & -2.29147 & {$[-0.42349]$} \\
\hline D(CPI_IND(-1)) & 0.465849 & {$[0.02846]$} \\
\hline
\end{tabular}

Table 2. Long Term

\begin{tabular}{|l|l|l|}
\hline \multicolumn{3}{|c|}{ Long Term } \\
\hline IPI_IND(-1) & 395.6043 & {$[1.78130]$} \\
\hline OIL(-1) & 43.48161 & {$[2.13319]$} \\
\hline ER_IND(-1) & 41.45236 & {$[0.44360]$} \\
\hline DJIA(-1) & -321.364 & {$[-3.73606]$} \\
\hline CPI_IND(-1) & 358.2504 & {$[1.45989]$} \\
\hline
\end{tabular}


Based on the estimation of VECM in ISSI model, it explains that in the short term IPI variable, world oil price, exchange rate of rupiah to dollar, DJIA and CPI have no significant effect on ISSI variable. While in the long term, world oil prices have a significant positive effect on ISSI with coefficient value of 43,481 units. While world oil prices increase by one unit, it takes affect the increase of ISSI value of 43,481 units. The rise in world oil prices will affect the psychology of investors or traders in buying shares related to world oil prices (Trømborg \& Solberg, 2010). The high demand caused by rising world oil prices that affect the rise of the index (Ftiti \& Hadhri, 2019). Although basically in the rill sector it burden the company in the cost of production, yet the rise of world oil prices is in response more quickly and positively than in the real sector. In addition,comparing to the relatively low world oil prices from 20142016, the world oil price hike is relatively less burdening on the real sector ofthose 2011-2013.

Conversely, the Dow Jones Industrial Average (DJIA) variable in the long run has a negative effect on ISSI with coefficient value of $-321,364$ units. This means if the Dow Jones Indusrial Average increased one unit,it will lower the index by 321,364 units. The majority of the largest investors in the capital market in Indonesia are foreign investors, where they easily move their funds to the US capital market due to the increasingly integrated world capital market (Habib, 2017). DJIA can describe the performance of the American economics. As the value of the DJIA index increases, it indicates an improved performance of the American economics. It may cause foreign investors to withdraw their investments from Indonesia and divert them to America. 


\section{Analyzing IRF}

\section{Graphics 1. Response of ISSI}

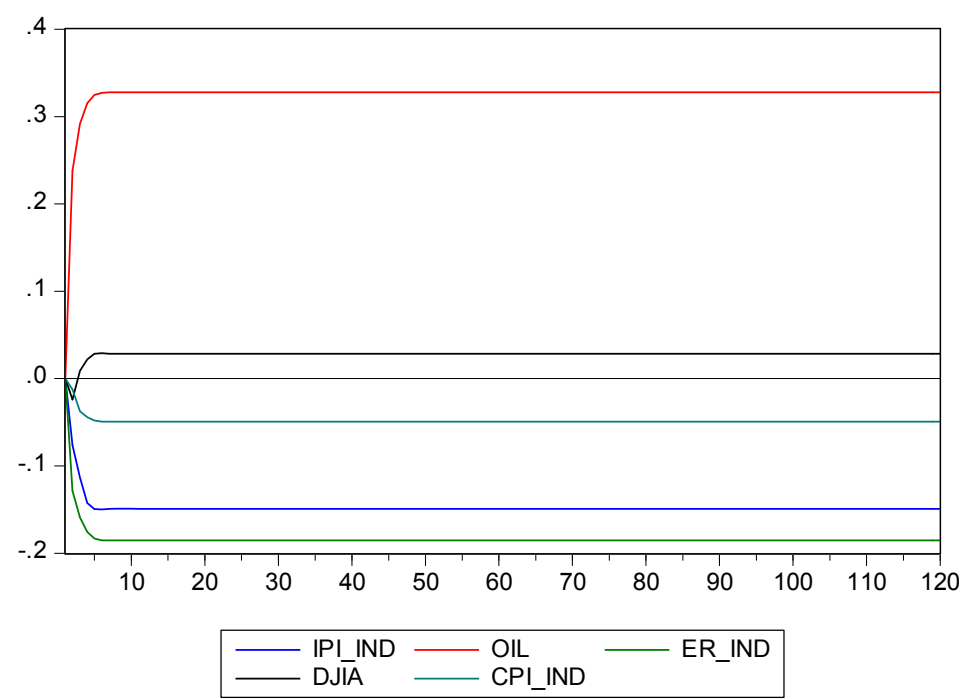

After such pre-estimation as root unit test, VAR stability test, optimum lag test and cointegration test, the model can be used to see the short and long-term effects through VECM estimation. The graphic 1 is the impulse response function (IRF) in the ISSI model. The results listed explain how the response of Indonesia Sharia Stock Index while there is a shock on the variables IPI, CPI, DJIA, exchange rate against dollar and world oil price. While the shock to DJIA and world oil price happened, ISSI positively response to world oil price; ISSI reach stability in period 7-8 until the next period. Similar to the shocks occur in the DJIA, Indonesia Sharia Stock Index goes to respond positively and reach a similar stability that is in the period of eight (8) to the end of the period (Aisiyah, 2015).

Negative responses occur at ISSI when there is a shock to the CPI. At the same level,the ISSI undergoes stable CPI shocks in the 6th and 
permanent periods until the next period (Beik, 2014). If ISSI get negative response; there is shock to IPI and rupiah exchange rate against dollar. ISSI experiences stability of IPI shocks in 4-5 periods. Along with the rupiah exchange rate, ISSI stability toward the exchange rate of rupiah against the dollar reaches at the period to 5 . From the five variables that have been described previously, it can be conclude that ISSI achieve a fast stability in the five variables. ISSI reaches a stability of no more than 10 periods.

\section{Analyzing FEVD}

Graphics 2. FEVD

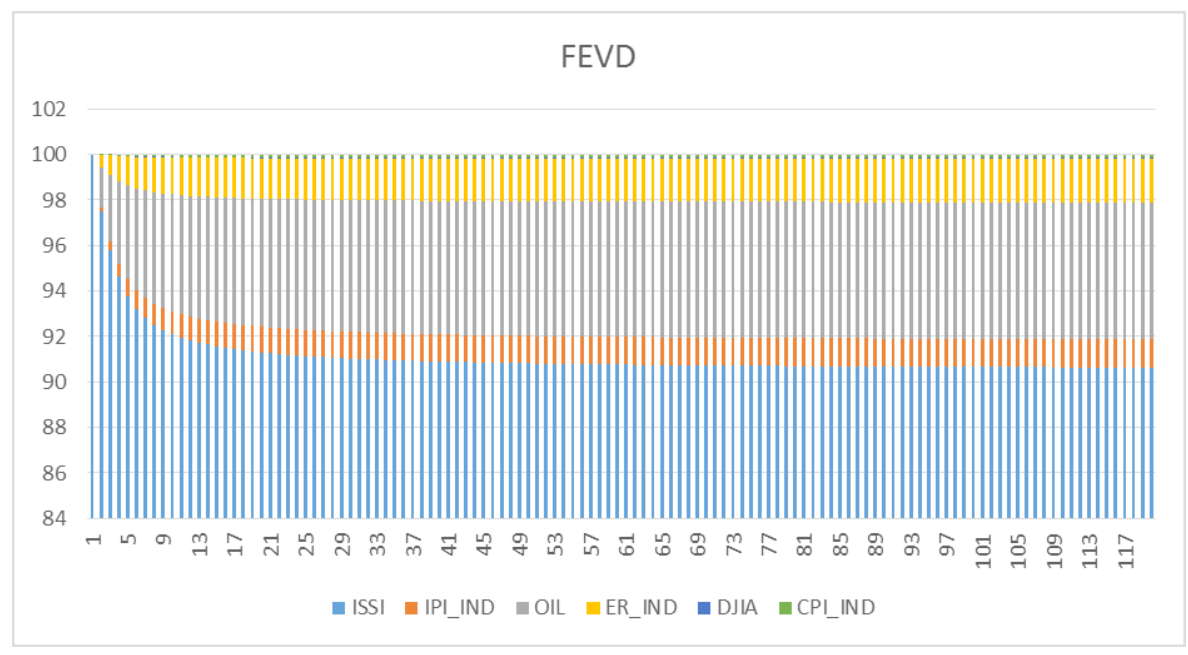

After analyzing on Impulse Response Function, it important to see the contribution of each variable in the ISSi model that will be seen in the Forecasting Error Variance Decomposition (FEVD). The behavior of Indonesia Sharia Stock Index (ISSI) is mainly influenced by ISSI itself with contribution of $90.6 \%$. Following world oil price (OIL) with contribution of $6.02 \%$, Rupiah Exchange Rate have against US Dollar (er_IND) with 
1.91\% contribution, Industrial Production Index (IPI) with contribution of $1.24 \%$, Consumer Price Index (CPI) with contribution of $0.134 \%$ and the last is Dow Jones Industrial Average (DJIA) with contribution sebsar $0.0449 \%$. Thus, the largest variables contribute to ISSI isthe world oil prices. The increasing mining sector (mining and oil) mostly take such effect on the sharia stock index. World oil prices often have been alleged as representative ofthe world economic improvement (Ftiti \& Hadhri, 2019). This study investigates the causal relationships between economic policy uncertainty, oil prices, investor sentiment, and stock returns of nine Dow Jones Islamic Market Indices.

Specifically, this article analyzes the causal effect of these variables on Islamic stock returns at different time scales using the ensemble empirical mode decomposition model. First, we decompose the economic policy uncertainty proxy, oil prices, and investor sentiment into different independent components called intrinsic mode functions (IMFs): shortterm IMFs designate the effects of irregular events; medium-term IMFs present the effects of extreme events; and long-term IMFs capture longterm effects. Second, we employ a nonlinear non-parametric causality model to test the causal relationship between different variables and Islamic stock returns at both the original and decomposed levels. We find causal relationships between the underlying variables and Islamic stock returns in several time frequencies rather than in the whole sample period. Our results suggest that the use of lagged economic policy uncertainty, oil prices, and investor sentiment may improve the predictability of Islamic stock returns. A test of forecast accuracy indicated the robustness of our results (Ftiti \& Hadhri, 2019). As rising oil prices reflect the demand of oil that have engaged in economic activities. 


\section{Discussing the Capital Market}

In the concept of economic growth, the capital market has an important role in the economic development of a country (Habib, 2017). It has two benefits. First, provide long-term financing for the business world and use it optimally to expand the company. Second, it becomes a intermediary for the society to invest in various forms of investment instruments such as mutual funds, stocks and others according to sharia principles (Basov \& Bhatti, 2014; Abdul Rahman, Muhammad, Ahmed, \& Amin, 2016; Ahiadorme, Gyeke-Dako, \& Abor, 2018). In addition, the stock price value of the capital market comes to the core consideration for investing such fund (Bian, Lin, \& Liu, 2018). The stock prices are not only influenced by economic factors and domestic phenomena, but external factors outside the country is very influential on the performance of sharia stocks also (Aloui, Hammoudeh, \& Hamida, 2015; Azizah, Satria, \& Wahyudi, 2016; Dash \& Maitra, 2018).

The role of the government would be necessary to create a good macroeconomic condition. The government should take policies on regulating economic elements. Creating a good economic stability set up a more conducive economics and attracts the local and international investors (Septyanto, Sudarwan, \& Dewanto, 2017; Rashid, Hassan, \& Yein, 2014; Ftiti \& Hadhri, 2019). Although Indonesia has the largest Muslims population, yet the development of sharia-based capital market is still densely packed far behind compare to that of Malasyia. The table below briefly explains the growth of sharia stock index value in Indonesia that has increased every year, although the index value is relatively small compare to the stock price index (JKSE). 


\section{Table 3. Comparison of ISSI and JII}

The Growth ISSI and JII 2011-2016

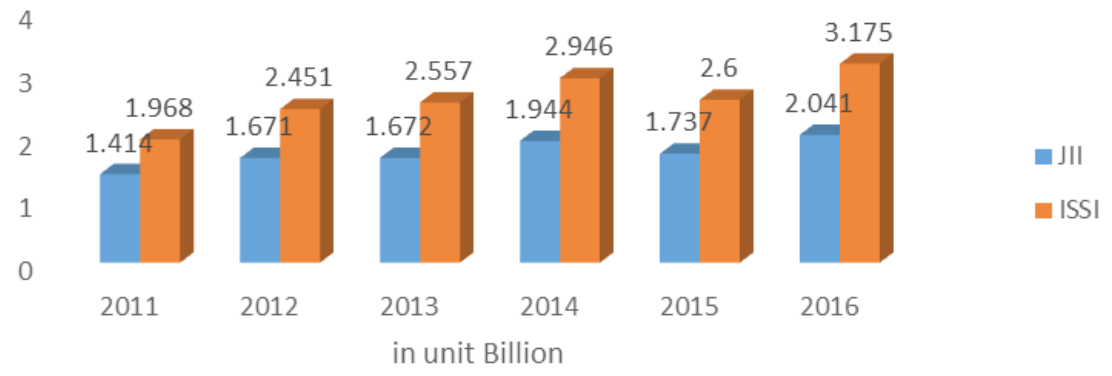

Data Source: OJK Statistical Data

The growth of sharia capital market reflected by Indonesia Sharia Stock Index (ISSI) and Jakarta Islamic Index (JII) in 2011-2016 underwent a relatively significant growth. Albeit it decline in 2015, instead in 2016 both reached the greatest capitalization value for six years.

Table 4. Amount Sharia Stock 2011-2016

Amount Sharia Stock)

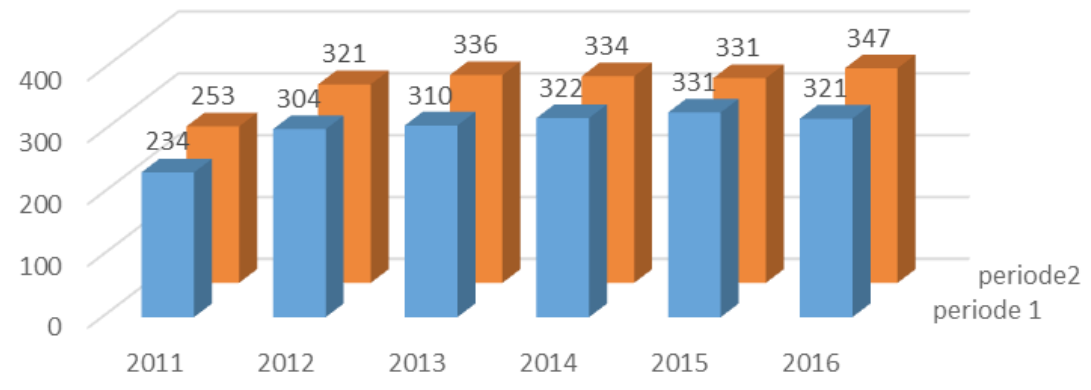

aperiode 1 periode2

Data Source: OJK Statistical Data 
In addition, the growth of capitalization in the Indonesia Sharia Stock Index is also followed by the growth of companies included in the list of sharia securities. The graphics above shows the number of listed companies in the list of sharia securities that experienced is latively significant growth over the six years from 2011 to 2016. It is also interesting that based on the State of the Global Islamic Economics 2016, from the total global Islamic financial assets, Indonesia is one of the countries in Southeast Asia that belongs to 10 countries of the largest sharia financial market in the world. Malaysia is currently the largest Islamic financial market in the world (Antonio, 2013; Khan, 2014). With a total population of about 250 million people, Indonesia potentially become the largest market share of Islamic finance in the near future.

The sharia capital market performance in Indonesia will be reflected through Indonesia Sharia Shares Index. This index is a sharia stock index that reflects the total sharia shares listed on the Indonesia Stock Exchange (Septyanto et al., 2017). Through the development of sharia capital market in Indonesia, the capital market industry in Southeast Asia began to apply Islamic Sharia principles as an alternative instrument of investment in capital market activities, while each country has different characteristics to develop and promote the Islamic finance industry, especially in the Sharia Capital Market.

The development of sharia capital market in Southeast Asia can not be separated from the role of religious authority especially Muslim-majority countries which have reaffirmed that usury is haram and prohibited in Islamic sharia (Blowfield, 2012). Similar to the Indonesian Ulama Council which has also issued a fatwa that bank interest is usury and haram. The fatwas are based on interpreted sharia principles in the Qur'an and the Sunnah of the Prophet. On the basis of this awareness, sharia capital market may begin to be developed. Moreover, the development of the Islamic 
finance industry, especially the capital market, is not only influenced by the religious nature or the majority Muslim population, instead also influenced by macroeconomic variables either through external factors or internal factors.

\section{Conclusion}

In VECM estimation ofISSI model, it confirms that in the short term IPI variable, world oil price, exchange rate of rupiah to dollar, DJIA and CPI does not significantly influence ISSI variable. While in the long term, world oil prices have a significant positive effect on ISSI. On the other hand, Dow Jones Industrial Average (DJIA) variable in the long run has a negative effect on ISSI. Impulse Response Function (IRF) shows that in ISSI model, DJIA shock and world oil price, ISSI has a positive response to world oil price, where ISSI reach stability in the period 7-8 until the next period. Similar to the shocks that occur in the DJIA, Indonesia Sharia Stock Index goes come to have positive response and reach a relatively similar stability that is in the period of 8 to the end of the period.

A negative response occurs at ISSI when there is a shock to the CPI, where the ISSI experiences stable CPI shocks in the 6th and permanent periods until the next period. In the case of the IPI variable and Rupiah exchange rate, ISSI get responds negatively when there is shock to IPI and rupiah exchange rate against dollar. ISSI underwent stability of IPI shocks in 4-5 periods. Similar to the rupiah exchange rate, ISSI stability against the exchange rate of rupiah against the dollar at the period to 5. The Forecast Error Variance Decomposition (FEVD) confirms that the value of ISSI is the most important by ISSI itself with a contribution of 90.06 . This is followed by world oil price (OIL) with contribution of $6.02 \%$, Rupiah Exchange Rate to US Dollar (er_IND) with 1.91\% contribution, Industrial Production Index (IPI) with contribution of $1.24 \%$, Consmer 
Price Index (CPI) with contribution of $0.134 \%$ and the last is Dow Jones Industrial Average (DJIA) with contribution sebsar 0.0449\%. 


\section{References}

Abdul Rahman, R., Muhammad, A. D., Ahmed, S., \& Amin, F. (2016). Micro-entrepreneurs' intention to use Islamic micro-investment model (IMIM) in Bangladesh. Humanomics, 32(2), 172-188. https:// doi.org/10.1108/H-02-2016-0020.

Ahiadorme, J. W., Gyeke-Dako, A., \& Abor, J.Y. (2018). Debt holdings and investment cash flow sensitivity of listed firms. International Journal of Emerging Markets, 13(5), 943-958. https://doi.org/10.1108/ IJoEM-04-2017-0126.

Aisiyah, S. S. (2015). Analisis dampak variable makro ekonomi terhadap indeks Saham Syariah Indonesia (ISSI).

Alhifni, A., Huda, N., Anshori, M., \& Trihantana, R. (2017). WAQF an instrument of community empowerment in Islamic Boarding School Daarut Tauhiid in Indonesia. Journal of Islamic Economics, Banking and Finance, 13(2), 76-88.

Al-Majali, A. A. (2014). Long-Run And Short-Run Relationship Between Stock Market Index And Main Macroeconomic VariablesPerformance In Jordan. European Scientific Journal.

Aloui, C., Hammoudeh, S., \& Hamida, H. B. (2015). Global factors driving structural changes in the co-movement between sharia stocks and sukuk in the Gulf Cooperation Council countries. North American Journal of Economics and Finance, 31, 311-329. https://doi. org/10.1016/j.najef.2014.12.002.

Amin, H., Abdul Rahman, A. R., Abdul Razak, D., \& Rizal, H. (2017). Consumer attitude and preference in the Islamic mortgage sector: a study of Malaysian consumers. Management Research Review, 40(1), 95-115. https://doi.org/10.1108/MRR-07-2015-0159.

Andri, S. (2010). Bank dan Lembaga Keuangan Syariah 7. Jakarta: Kencana. 
Antonio, M. S. (2013). Votalitas Pasar Modal Syariah dan Indikator Makroekonomi :Study Banding Malaysia dan Indonesia. Jurnal Nasional.

Arsana, I. G. P. (2004). VAR (Vector Auto Regressive). Jakarta: Laboratorium Komputasi Ilmu Ekonomi FEUI.

Ascarya. (2009). Aplikasi Vector Autoregression dan Vector Error Correction Model Menggunakan Eviews 4.1.

Asmy, et al, M. (2010). Asmy, Mohamed.et all, Efect of macroeconomic variable on stock prices in malaysia: An Aproah of Error Correlation Model. MPRA Paper.

Basov, S., \& Bhatti, M. I. (2014). On Sharia'a-compliance, positive assortative matching, and return to investment banking. Journal of International Financial Markets, Institutions and Money, 30(1), 191195. https://doi.org/10.1016/j.intfin.2013.12.010

Battiati, C. (2019). R\&D, growth, and macroprudential policy in an economy undergoing boom-bust cycles. Journal of Macroeconomics, 59, 299-324. https://doi.org/10.1016/j.jmacro.2018.12.007.

Beik, I. S. (2014). Pengaruh Indeks Harga Saham Syariah Internasional Dan Variabel Makro Ekonomi Terhadap Jakarta Islamic Index. Jurnal Istishad: Jurnal Ilmu Ekonomi Syariah.

Bian, X., Lin, Z., \& Liu, Y. (2018). House price, loan-to-value ratio and credit risk. Journal of Banking and Finance, 92, 1-12. https://doi. org/10.1016/j.jbankfin.2018.04.006

Blowfield, M. (2012). Business and development: Making sense of business as a development agent. Corporate Governance (Bingley), 12(4), 414426. https://doi.org/10.1108/14720701211267775.

Dash, S. R., \& Maitra, D. (2018). Does Shariah index hedge against sentiment risk? Evidence from Indian stock market using timefrequency domain approach. Journal of Behavioral and Experimental Finance, 19, 20-35. https://doi.org/10.1016/j.jbef.2018.03.003. 
Dimic, N., Kiviaho, J., Piljak, V., \& Äijö, J. (2016). Impact of financial market uncertainty and macroeconomic factors on stock-bond correlation in emerging markets. Research in International Business and Finance, 36, 41-51. https://doi.org/10.1016/j.ribaf.2015.09.001.

Fareed, S., Arsalan, T., \& Ayubi, S. (2017). Bank deals with liquidity: The micro and macroeconomic determinants approach evidence from Pakistan (Vol. 2017-January, pp. 1073-1086). Presented at the Proceedings of the 30th International Business Information Management Association Conference, IBIMA 2017 - Vision 2020: Sustainable Economic development, Innovation Management, and Global Growth.

Ftiti, Z., \& Hadhri, S. (2019). Can economic policy uncertainty, oil prices, and investor sentiment predict Islamic stock returns? A multiscale perspective. Pacific Basin Finance Journal, 53, 40-55. https:// doi.org/10.1016/j.pacfin.2018.09.005.

Gujarati, D. (2003). Ekonometrika Dasar. Erlangga, Jakarta. Jakarta: Erlangga.

Habib, F. (2017). The issue of speculation in the Islamic capital market. Journal of Islamic Economics, Banking and Finance, 13(2), 89-101.

Hsing, Y. (2011). Macroeconomic Determinants of the Stock Market Index and Policy Implications: The Case of a Central European Country. Eurasian Journal of Business and Economics 2011.

Khan, A. (2014). Sharia stock Index and Economix Activity in Malaysia: is there a connection. Journal of Islamic Economics.Banking and Financing April-June 2014.

Mohd Thas Thaker, M. A. B. (2018). Factors influencing the adoption of the crowdfunding-waqf model (CWM) in the waqf land development. Journal of Islamic Marketing, 9(3), 578-597. https://doi.org/10.1108/ JIMA-05-2016-0043.

Mohd Thas Thaker, M. A. B., \& Allah Pitchay, A. (2018). Developing waqf land through crowdfunding-waqf model (CWM): the case of 
Malaysia. Journal of Islamic Accounting and Business Research, 9 (3), 448-456. https://doi.org/10.1108/JIABR-05-2016-0062.

Naseri, M., \& Mansur Masih. (2014). Causality between Malaysian islamic Stock Market and Macrowconomic Variables. MPRA Paper.

Nur Azizah, T., Satria, D., \& Tri Wahyudi, S. (2016). The impact of macroeconomic fundamentals on the Indonesian Sharia stock index. Journal of Applied Economic Sciences, 11(5).

Rashid, M., Hassan, K. M., \& Yein, N. Y. (2014). Macroeconomics, investor sentiment, and Islamic stock price index in Malaysia. Journal of Economic Cooperation and Development, 35(4), 221-236.

Septyanto, D., Sudarwan, \& Dewanto, I. J. (2017). Model behavior of Sharia investment decision on Muslim investor in Indonesia stock exchange (IDX). International Journal of Economic Research, 14(4), 353-363.

Trømborg, E., \& Solberg, B. (2010). Forest sector impacts of the increased use of wood in energy production in Norway. Forest Policy and Economics, 12(1), 39-47. https://doi.org/10.1016/j. forpol.2009.09.011. 
Vol. 3 No. 2, May - August 2018 


\section{Shirkah Author Guidelines}

Shirkah currently offers two routes to submit manuscripts. We highly recommend to submit the articles which are made using OJS (Open Journal System). Feel free register as author soon through visiting http:// shirkah.or.id/index.php/home/user/register. The authors may directly send their manuscripts, along with their resume, to shirkahiainsurakarta@ gmail.com. Please prepare your manuscripts, using following guidelines:

1. Manuscript must be written in English. Submitted articles should not have been published or be under review for publication with another journal.

2. Manuscript's length is about $15-20$ pages, typed in one-half spaced on A4-paper size.

3. Manuscript must include an $150-200$ word abstract and keywords.

4. Manuscript must be arranged as follows: Title, Name of Author, E-mail address, Abstract, Keywords, Introduction (including method if any), Discussion, Conclusion, References.

5. Manuscript's titles not more than ten words.

6. Manuscript must be submitted in Microsoft Word or RTF.

7. Arabic words should be transliterated according to the style of International Journal of Middle Eastern Studies.

8. Manuscript references are preferably derived from the up-to-date references.

9. The author's resume should be submitted separately, consisting of at least full name, institutional address, phone number, areas of studies, and recent publications (if any).

10. Shirkab use APA Style 6th edition (2010) as reference format writing. We suggest the use of a reference manager software such as Mendeley, Zotero, and Endnote at templating the citation style. APA Style to be used is as follows: 


\section{Book with single author}

Swann, G. M. Peter. (2014). The Economics of Innovation an Introduction. Cheltenhum \& Northampton: Edward Elgar.

in-text citation: (Swann, 2014)

\section{Articles in reference books}

Alatas, S. F. (2006). Islam and the Science of Economics in Abu Rabi', I.M. The Blackwell Companion to Contemporary Islamic Thought. USA: Willey-Blackwell (pp. 587-606).

in text citation: (Alatas, 2006)

\section{E-Book}

Hackett, Rosalind (2007). "Religous Dimentions of War and Peace: Introduction.” Dalam Gerrie ter Haar dan Yoshio Tsuruoka (Ed.), Religion and Society: An Agenda for the 21st Century (h. 3-6). Retrieved from http:// brill.nl.

in text citation: (Hackett, 2006)

\section{Master's thesis, from a commercial database}

McNieI, D. S. (2006). Meaning through narrative: A personal narrative discussing growing up with an alcoholic mother (Master's thesis). Available from ProQuest Dissertations and Theses database. (UMI No. 1434728)

in text citation: (Mc Niel, 2006)

\section{Doctoral dissertation, from an institutional database}

Adams, R. J. (1973). Building a foundation for evaluation of instruction in higher education and continuing education (Doctoral dissertation). Retrieved from http://www.ohiolink.edu/etd/

in text citation: (Adams, 1973) 


\section{Doctoral dissertation, from the web}

Bruckman, A. (1997). MOOSE Crossing: Construction, community, and learning in a networked virtual world for kids (Doctoral dissertation, Massachusetts Institute of Technology). Retrieved from http:/www-static. cc.gatech.edu/--asb/thesis/

in text citation: (Bruckman, 1997)

\section{Journal article with No DOI}

Bourkhis, K., and Nabi, M. S. (2013). Islamic and conventional banks' soundness during the 2007-2008 financial crisis. Journal Metrics, 22(2), 68-77.

in-text citation: (Bourkhis \& Nabi, 2013).

\section{Journal article with DOI}

Ichwan, M. (2012). The Local Politics Of Orthodoxy: The Majelis Ulama Indonesia in the Post-New Order Banten. Journal Of Indonesian Islam, 6(1), 166-194. doi:http://dx.doi.org/10.15642/JIIS.2012.6.1.166-194

In text citation : (Ichwan, 2012)

\section{Abstract as citation}

Hasan, N. (2012). Islamist Party, Electoral Politics And Da'wah Mobilization Among Youth : The Prosperous Justice Party (PKS) in Indonesia. Journal of Indonesian Islam, 6(1), 17-47. Abstract from http:// jiis.uinsby.ac.id/index.php/jiis/article/view/97

in text citation : (Hasan, 2012)

\section{Mass media article}

Sahal, Akhmad (2014, March 2). Kiai Sahal dan Realisme Fikih.Tempo Magazine, p. 120.

in text citation : (Sahal, 2014) 


\section{Research report}

Fisher, B. S., Cullen, F. T., \& Turner, M. G. (2000). The Sexual Victimization of College Women. Research Report.

in text citation : (Fisher, Cullen, Turner, 2000)

\section{Monograph}

Routray, Bibhu Prasad (2013), National Security Decision-Making in India (RSIS Monograph No. 27). Singapura: Rajaratnam School of International Studies.

in text citation : (Routray, 2013)

\section{Proceeding article}

Sudibyakto, Hizbaron, D.R., \& Jati, R (Ed.) (2009), Proceeding International Seminar Disaster Theory, Research and Policy. International seminar held by Sekolah Pascasarjana, Universitas Gajahmada, Yogyakarta, 8-9 Desember 2009.

in text citation : (sudibyakto and Jati, 2009)

\section{Paper conference/seminar/symposium}

Janutama, Herman Sinung (2011). "Kraton dan Hubungan Antar Agama." Paper presented in Seminar Kraton dan Panatagama held by Center for the Study of Islam and Social Transformation (CISForm), Yogyakarta, 17 November.

in text citation :(Janutama, 2011)

\section{Online article in web}

Shiva, (2006, February). Bioethics: A Third World Issue. Native-web. Diperoleh dari http://www.nativeweb.org/ pages/legal/shiva.html

in text citation : (Shiva, 2006) 


\section{Online research report}

Kessy, S. S. A., \& Urio, F M. (2006). The contribution of microfinance institutions to poverty reduction in Tanzania (Research Report No. 06.3). Retrieved from Research on Poverty Alleviation website: http://www. repoa.or.tz /documents_storage/Publications/Reports/06.3_Kessy_and_ Urio.pcif

in text citation : (kessy and urion, 2006)

\section{Holy book}

Qur an, $2(25)$

In text citation : (Q. al-Baqarah 2:25).

\section{Encyclopaedia}

Graycar, Adam (1992). Social Welfare Policy. Dalam Mary Hawkesworth dan Maurice Kogan (Ed.), Encyclopedia of Government and Politics (Vol. 1). London: Routledge.

in text citation : (Graycar, 1992)

\section{Interview}

Sultan Hamengkubuwono X (interview, 2011, April 19)

in text citation: (Hamengkubuwono, 2011)

\section{Documentary film}

Steijlen, Fridus (2008). A Day in the Life of Indonesia [documentary film, 58 minutes]. Leiden: KITLV Press.

in text citation : (Steijlen, 2008) 
Vol. 3 No. 2, May - August 2018 